\title{
Use of Cucurbit [6] Uril as a Modifier in the Electrochemical Determination of Antitumor Platinum (II) Complex: Trans-[ $\mathrm{PtCl}_{2}$ (Dimethylamine) (Isopropylamine)]. Application to Biological Samples
}

\author{
Carmen S. H. Domínguez*, Pedro Hernández \\ Departamento de Química Analítica y Análisis Instrumental, Facultad de Ciencias, Universidad Autónoma de Madrid, \\ Cantoblanco, Madrid, Spain \\ Email: * carmen.hernandez.dominguez@gmail.com
}

Received April 2, 2013; revised May 3, 2013; accepted June 1, 2013

Copyright (C) 2013 Carmen S. H. Domínguez, Pedro Hernández. This is an open access article distributed under the Creative Commons Attribution License, which permits unrestricted use, distribution, and reproduction in any medium, provided the original work is properly cited.

\begin{abstract}
A square wave voltammetry (DPV) method for trans- $\mathrm{Pt}\left[\mathrm{Cl}_{2}\right.$ (Dimethylamine)(isopropylamine)] determination is developed. To this end, all the chemical and instrumental variables affecting the determination of trans $-\mathrm{Pt}\left[\mathrm{Cl}_{2}\right.$ (Dimethylamine) (isopropylamine)] are optimized. From studies of the mechanisms governing the electrochemical response of trans$\mathrm{Pt}\left[\mathrm{Cl}_{2}\right.$ (Dimethylamine)(isopropylamine)], it was concluded that it was an electrochemically reversible system with an adsorptive oxidation phenomenon. Under optimal conditions, the variation of analytical signal (Ip) with trans$\mathrm{Pt}\left[\mathrm{Cl}_{2}\right.$ (Dimethylamine)(isopropylamine)] concentration was linear in the $0.05 \mu \mathrm{g} \cdot \mathrm{mL}^{-1}$ to $10 \mu \mathrm{g} \cdot \mathrm{mL}^{-1}$ range, with a LOD $91 \mu \mathrm{g} \cdot \mathrm{mL}^{-1}$ of and a LOQ of $303 \mu \mathrm{g} \cdot \mathrm{mL}^{-1}$, a RSD $1.10 \%$ and $\operatorname{Er} 0.72 \%$. The optimized method was applied to the determination of trans- $\mathrm{Pt}\left[\mathrm{Cl}_{2}\right.$ (Dimethylamine)(isopropylamine)] in biological fluids, in human urine and synthetic urine.
\end{abstract}

Keywords: Trans-Pt[Cl ${ }_{2}$ (Dimethylamine)(Isopropylamine)]; Differential Pulse Voltammetry (DPV); Square Wave Voltammetry (SWV); Biological Fluids; Human Urine

\section{Introduction}

In the 40 years since the discovery of cisplatin, hundreds of new platinum (II)- and platinum (IV)-based complexes have been synthesised and tested as anticancer drugs [1]. From these, only carboplatin and oxaplatin have received world-wide approval [2]. Several new drugs are in various stages of clinical trials [3-5]. All these drugs have similar structures, that is: one or more platinum atoms coordinated to amine or ammine carrier ligands and chloro, carboxylate, oxalate or acetate leaving groups [1]. Because they share similar structures, their mode of actions is the same, they are all susceptible to the development of drug resistance, and all display severe dose-limiting toxicities.

Better delivery can be achieved through drug encapsulation inside a variety of macromolecules and two such strategies for the delivery of oxaplatin using liposomes $[6$,

${ }^{*}$ Corresponding author.
7] and polymers [8-11] are currently being investigated. Encapsulation of drugs inside a macromolecule provides two benefits. Firstly, it protects the drugs from degradation by using steric hindrance to prevent the close approach of nucleophiles, particularly glutathione and thiol or thiolate-containing proteins. Secondly, encapsulation can increase the specificity of the drugs for, and uptake into, cancerous cells, through the enhanced permeability and retention effect [12]. Cancerous cells are porous, having cavities that are up to $1000 \mathrm{~nm}$ in diameter and which are able to trap and retain large molecules more effectively than normal cells [12].

As well as liposomes and polymers, platinum drugs can also be encapsulated by small macrocycles. Cyclodextrins are cyclic oligosaccharides composed of $\alpha$-D-glucose subunits, and are already used extensively in formulations of organic drugs [13]. In vitro experiments demonstrated that the cyclodextrin-platinum complexes were completely inactive; no other in vitro results have yet 
been reported.

Recently, a family of small macrocycles called cucurbit $[n]$ urils $(\mathrm{CB}[n])$ has shown utility as drug delivery vehicles.

Whilst cucurbit [6] uril (CB [6])was first discovered in 1905 by Behrend et al. [14], its macrocyclic structure was not determined until 1981 [15] and until 2000, CB [6] was the only cucurbit $[n]$ uril to receive any attention as a molecules useful in host-guest chemistry. This changed upon the discovery of different sized cucurbit $[n]$ urils: $\mathrm{CB}$ [5], $\mathrm{CB}$ [7], $\mathrm{CB}$ [8] and the isolation of free $\mathrm{CB}$ [10] ((compound 3, 5, 6, Figure 1) [16,17]. Their discovery has led to a rapid increase in the interest in, and application of, $\mathrm{CB}[n]$ in a variety of fields including: nanomachines, chromatography and drug delivery [18]. Cucurbit $[n]$ urils, named for its distinctive pumpkin-like shaped, is made from the condensation of glycoluril and formaldehyde in strongly acidic solutions $[19,20]$. Synthesis yields a mixture of different sized molecules, where the ratios of products can be tuned by varying the acid concentration or type [21].

Cucurbit $[n]$ urils contain two hydrophilic carbonyl lined portals, capping a central hydrophobic cavity. The different sizes of the portals and cavities means they are able to bind a variety of organic and inorganic molecules. A variety of organic drugs and biologically relevant molecules have been encapsulated in CB $[n]$.

Of most use in platinum drug delivery are $\mathrm{CB}$ [6], $\mathrm{CB}$ [7] and $\mathrm{CB}$ [8]. The portal of CB [5] is too small to allow the entry of coordinated platinum atoms and many organic ligands, and the cavity of $\mathrm{CB}[10]$ is generally too large to strongly hold a platinum complex when dissolved at biological concentrations $\left(\mathrm{k}_{\mathrm{b}}>\mu \mathrm{M}\right)$. Cucurbit $[n]$ urils are sparingly soluble in water, but become more soluble upon encapsulation of some platinum complexes, particularly cationic and/or multinuclear complexes. The solubility of $\mathrm{CB}[n] \mathrm{s}$ in water also varies depending on the method used to synthesise and purify them; many $\mathrm{CB}[n] \mathrm{s}$ precipitate from solution with co-crystallised acid molecules [21], which can be difficult to remove. Alkali earth metal salts also increase the solubility of $\mathrm{CB}[n] \mathrm{s}$, particularly saline [22-27]. In the latter case, the cations are strongly bound at the portals and can help stabilise the binding of small guests inside the cavity [22-27].

Chiral $\mathrm{CB}[n] \mathrm{s}$ that are capable of recognising and binding chiral guest [28] have been synthesised which have an application in the delivery of chiral drugs. CB [n] $s$ have also been found to form monolayers on gold surfaces, which have applications in cancer diagnosis. [29]

Full or partial encapsulation of platinum complexes is stabilised through hydrophobic interactions within the $\mathrm{CB}[n]$ cavity and through ion-dipole and dipole-dipole interactions at the portals $[19,20]$. The mode of binding can be examined using nuclear magnetic resonance
(NMR).

Instead, the location of a drug's proton(s) inside the $\mathrm{CB}[n]$ cavity is determined from the change in the chemical shift of their ${ }^{1} \mathrm{H}$ resonance. Protons within a $\mathrm{CB}[n]$ cavity are highly shielded and can shift upfield (lower $\mathrm{ppm} /$ frequency) by up to $1.5 \mathrm{ppp}$ [30]. Protons that are located outside, but close to, the portals are slightly deshieded and move downfield, whilst protons far away from the $\mathrm{CB}[n]$ do not change chemical shift [30].

The magnitude of the chemical shift change is directly proportional to the proton's depth within the $\mathrm{CB}[n]$ cavity or distance from the portal; a larger up field change in chemical shift implies that a proton is located deeper within the cavity than a proton that shifts to a lesser extent. Similar shielding/deshielding movements are also observed for platinum resonances in ${ }^{195} \mathrm{Pt}$ NMR spectra [30,31].

Platinum complexes which intercalate double-stranded DNA can also be partially encapsulated by $\mathrm{CB}[n] \mathrm{s}$. For a family of platinum (II)-based DNA intercalator complexes encapsulation by CB [6], CB [7] and CB [8] has been shown to occur predominantly over the hydrophobic ancillary ligands, S,S-dach and ethylene diamine (en) [31, 32].

The binding constants for many platinum complexes with $\mathrm{CB}[n]$ are strong enough to have application in drug delivery, with the exception of cisplatin; generally binding constants need to be greater than $10^{5} \mathrm{M}^{-1}$ for the hostguest complex to remain intact at biological concentrations.

Encapsulation of platinum complexes within CB $[n]$ has an affect on both the metal complexes' cytotoxicity and toxicity. $\mathrm{CB}[n]$ molecules all of sizes appear to have no intrinsic cytoxicity, with $\mathrm{IC}_{50}$ values of $>100 \mu \mathrm{M}$ in many human cancer cell lines. Similarly, $\mathrm{CB}[n] \mathrm{s}$ also appears to be relatively non-toxic, with in vivo studias in mice indicating that the maximum tolerated dose of $\mathrm{CB}$ [7] is around $200 \mathrm{mg} \cdot \mathrm{kg}^{-1}$ [30].

The effect of $\mathrm{CB}[n]$ on the cytotoxicity of platinum complexes appears to be related, to some extent, to the strength of the binding.

For a family of platinum (II)-based DNA intercalators, a clear correlation between CB $[n]$ size and cytotoxicity is harder to determine. $\mathrm{CB}[6]$ has a positive or only slightly negative effect on the cytotoxicity.

The observed general decrease in cytotoxicity that many metal complexes experience upon encapsulation by $\mathrm{CB}$ $[n] \mathrm{s}$ could arise for two different reasons. Firstly, it may be because encapsulation reduces the metal complexes' reactivity towards nucleophiles and these results in a slower rate of DNA binding or a reduction in the DNA adducts formed. Alternatively, $\mathrm{CB}[n]$ may affect the cellular uptake of the metal complexes and thus prevent sufficient concentrations of drug from entering cells and 
inducing apoptosis. Regardless of the mechanism causing the general decrease in metal complex cytotoxicity, this effect is manageable, provided that the reduction in vitro activity also equates to a reduction in the metal complexes' toxicity and an improvement of their therapeutic index.

In this paper, a new electrochemical method to determine trans $-\mathrm{Pt}\left[\mathrm{Cl}_{2}\right.$ (Dimethylamine)(isopropylamine) $]$ in biological fluids is developed.

The group of Dr. Carmen Navarro-Ranninger [33] has reported that the trans-platinum (II) complex with mixed aliphatic amines,

trans $-\mathrm{Pt}\left[\mathrm{Cl}_{2}\right.$ (Dimethylamine)(isopropylamine)] (Figure 1) circumvents cisplatin resistance in cells that overexpress ras oncogenes. In addition, compound 1 is also able to circumvent resistance to cisplatin an A2780cisR ovarian tumor cells, which exhibit resistance through a combonation of three mechanisms mentioned above [34]. Moreover, they observed that circumvention of cisplatin resistance by compound 1 is associated with a higher level of apoptosis induction relative to cis-diamminedichloroplatinum (II) (compound 1 Figure 1) [35,36]. Of interest also was the observation that in A2780cisR cells, there is a correlation between the DNA interstrand cross-linking efficiency of compound 1 and its ability to induce apoptosis [36].

This paper makes a study of the electrochemical behaviour of this compound by differential pulse voltammetry (DPV) aimed at obtaining the optimal conditions for its determination in biological fluids and the establishment of its formation constants.

The analysis of biological fluids presents a special relevance because small changes in the concentration of its components are through to be correlated with several neurological or metabolic disorders.

\section{Experimental}

\subsection{Reagents}

Trans- $\mathrm{Pt}\left[\mathrm{Cl}_{2}\right.$ (Dimethylamine)(isopropylamine)] [33], provided by Dr. Carmen Navarro-Ranninger. Buffer solutions prepared with acetic acid, phosphoric and boric

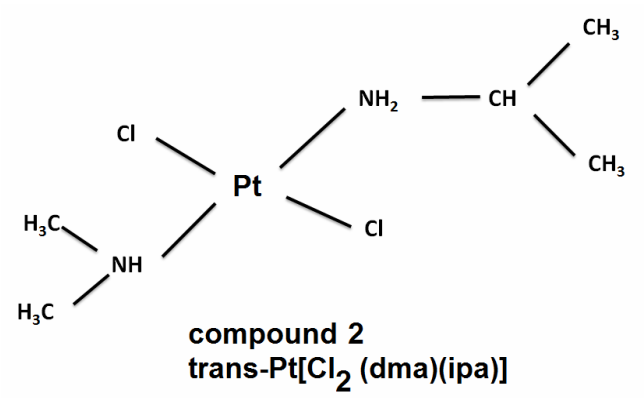

Figure 1. Structures of the molecules referenced in this work. adjusted to the desired value with sodium hydroxide. Unless otherwise stated, all other reagents were of analytical grade and used as received. Ultrapure water, obtained from Millipore MilliQ System (Waters), was used in the preparation of buffers and solutions and cleaning of the electrochemical

$\mathrm{Pt}\left[\mathrm{Cl}_{2}\right.$ (Dimethylamine)(isopropylamine) $]$ analysis sage. All the solutions were prepared just prior to use, conserved at $4^{\circ} \mathrm{C}$ and protected from light.

\subsection{Apparataus}

The electrochemical measurements were performed using a Bioanalytical System (BAS) Epsilon Potentiostat workstation. A conventional three electrode cell was used. In all experiments, a large area-coiled platinum wire was employed as a counter electrode, an $\mathrm{Ag} / \mathrm{AgCl} / \mathrm{KCl} 3 \mathrm{M}$ reference electrode and a platinum electrode was employed a work electrode. For $\mathrm{pH}$ adjustment, a $\mathrm{pH}$-meter Methrom C831 was employed as well a circulation ultrathermostat Frigiterm-10 (P-Selecta, Spain) to control the temperature.

\subsection{Procedure}

Trans- $\mathrm{Pt}[\mathrm{Cl}$ (Dimethylamine)(isopropylamine)] stock solution $\left(500 \mu \mathrm{g} \cdot \mathrm{mL}^{-1}\right)$ was prepared with ultrapure water and stored at $4^{\circ} \mathrm{C} \pm 1^{\circ} \mathrm{C}$ and preserved in aluminium foil covered bottles to avoid photo degradation. Prior to analysis, sample bottles were allowed to equilibrate to RT.

\subsection{Sample Preparation}

Trans- $\mathrm{Pt}\left[\mathrm{Cl}_{2}\right.$ (Dimethylamine)(isopropylamine)] was readily and further diluted to the desire concentrations using $0.5 \mathrm{M}$ acetic buffer solutions.

The samples used for the implementation of the method described above were a synthetic urine sample prepared at the laboratory and a sample of real human urine.

The composition of the synthetic urine is collected in Table 1 [37].

The treatment suffered by the human urine sample consisted of: 1) doping of the sample with an aliquot of complex trans- $\mathrm{Pt}\left[\mathrm{Cl}_{2}\right.$ (Dimethylamine)(isopropylamine) $]$ of $\left.10 \mu \mathrm{g} \cdot \mathrm{mL}^{-1} ; 2\right)$ precipitation of proteins with $\mathrm{HClO}_{4}$ $0.1 \mathrm{M} . ; 3$ ) digestion of the precipitate for a weekend (48 hours); 4) filtering of the sample; and 5) adjust the $\mathrm{pH}$ of the sample to the appropriate $\mathrm{pH}$.

\subsection{Electrode Activation}

In order to desorb the platinum (II)-cucurbit [6] uril complex from the electrode and to prepare the electrode for a new experiment, the activation and regeneration of the electrode surface was carried out by successive and multiple cyclic voltammetric scans in $0.5 \mathrm{M} \mathrm{H}_{2} \mathrm{SO}_{4}$ solution 
between 0.0 and $1.5 \mathrm{~V}$ at $100 \mathrm{mVs}^{-1}$.

\section{Results and Discussion}

The electrochemical study of the Pt(II) complex trans-[ $\mathrm{PtCl}_{2}$ (dimethylamine) (isopropylamine)] was performed by differential pulse voltammetry (DPV) and square wave voltammetry in order to determinate the best conditions for its determination.

\subsection{Studies with the Unmodified Electrode}

\subsection{1. pH Influence and Ionic Strength}

In order to select the optimum $\mathrm{pH}$ was employed a range of $\mathrm{pH}$ between $\mathrm{pH} 2$ and $\mathrm{pH}$ 12. The buffers used were phosphate buffer for $\mathrm{pH} 2,3,6,7,8,10,11$ and 12; acetic buffer for $\mathrm{pH} 4$ and 5; and boric buffer for $\mathrm{pH} 9$. The concentration of all of them was $0.5 \mathrm{M}$.

In Figure 2 are represented voltammograms obtained at different $\mathrm{pH}$ values, Figure 2(a) corresponds to the variation of peak intensity with respect to $\mathrm{pH}$ and Figure 2(b) to the variation of peak potential versus $\mathrm{pH}$. This figure shows that the greatest intensity is reached at $\mathrm{pH} 8$ (Figure 2(a)). By representing the variation of peak potential with respect to $\mathrm{pH}$ (Figure 2(b)) there are two straight sections with a clear variation of the slope, indicating that the compound under study has one dissociation constant, which correspond to the values of $\mathrm{K}=10$ 4.0 , in the first stage of the hydrolysis.

From the standpoint of electrochemistry, $\mathrm{pH} 8$ was chosen for further study because it is the $\mathrm{pH}$ value, which provides greater intensity.

It is also studied the necessary ionic strength necessary to achieve the highest possible sensitivity in the electrochemical reaction. In this study we used solutions of boric acid-borate buffer solution buffer $\mathrm{pH} 8$ concentrations between $5 \times 10^{-2}$ and $2.0 \mathrm{M}$, reaching maximum intensity to $5 \times 10^{-1} \mathrm{M}$, concentration used for further studies.

\subsubsection{Instrumental Variables}

Once the study of chemical variables, it was proceeded to the optimization of instrumental variables, both differential pulse voltammetry (DPV) and by square wave voltammetry (SWV) kept constant in both techniques the value of $\mathrm{pH} 8$ and ionic strength $5 \times 10^{-1} \mathrm{M}$, found above, and the concentration of analyte $\left(10 \mu \mathrm{g} \cdot \mathrm{mL}^{-1}\right)$.

1) Influence of Frequency

The frequency was changed, and the amplitude and the step (scan increment) were fixed in $25 \mathrm{mV}$ and $4 \mathrm{mV}$, respectively.

The relation obtained between the intensity and the square root of the frequency was linear: ip $(\mu \mathrm{A})=$ $60.298 \mathrm{f}^{1 / 2}(\mathrm{~Hz})-62.638, \mathrm{R}^{2}=0.991$; this relation indicated us the process of oxidation was controlled by diffusion.

The value of $80 \mathrm{~Hz}$ was chosen like optimal value of frequency for future studies because the waves obtained for this frequency has a good resolution.

2) Influence of Scan Increment (Step)

When the voltammograms for the study of step were registered (the pulse amplitude and the frequency were fixed in $25 \mathrm{mV}$ and $80 \mathrm{~Hz}$, respectively), we observed the peak intensity and the peak potentials were increased when he scan increment were increased.

The relations between the square root of the step and the peak intensity and peak potential were linear: $\mathrm{I}_{\mathrm{p}}(\mu \mathrm{A})$ $=2.022 \operatorname{step}^{1 / 2}\left(\mathrm{mVs}^{-1}\right)+1.542 ; \mathrm{R}^{2}=0.991 ; \mathrm{E}_{\mathrm{p}}(\mathrm{mV})=$ $16.97 \log \operatorname{step}\left(\mathrm{mVs}^{-1}\right)+10.16 ; \mathrm{R}^{2}=0.987$. The information provided to us in this study was identical to that obtained in the study of the frequency (process controlled for adsorption and irreversible electrochemically) because both studies relied on the scan rate. We choose a value of step of $2 \mathrm{mV}$ to maintaining constant scan rate and because we obtained the best resolution in the wave with a low peak potential value.

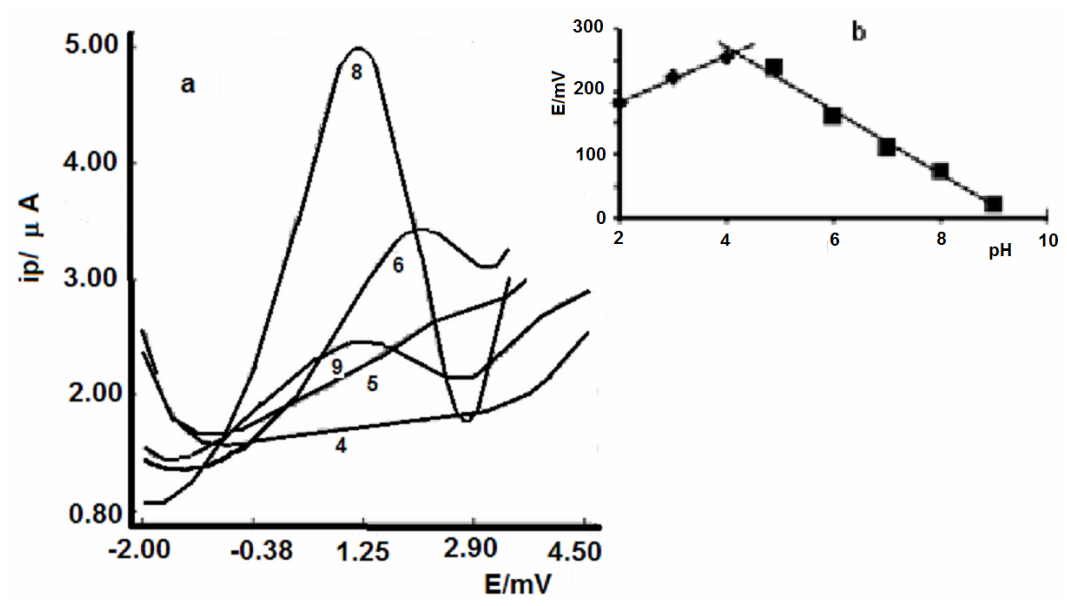

Figure 2. Voltammograms at diferente $\mathrm{pH}$ values. 
3) Influence of Pulse Amplitude

By changing this variable using differential pulse voltammetry, it appears that the peak current increases linearly according to equation. $\operatorname{ip}(\mu \mathrm{A})=0.0119 \Delta \mathrm{E}(\mathrm{mV})+$ 0.0607 ; using a scan rate of $25 \mathrm{mV} / \mathrm{s}$ throughout the study.

But at the same time increases the width of half-peak, so it is necessary to reach a situation of compromise between sensitivity and selectivity. This occurs at a value of pulse amplitude $50 \mathrm{mV}$.

The peak potential is modified according to the equation: $\mathrm{Ep}(\mathrm{mV})=-0.6825 \Delta \mathrm{E}(\mathrm{mV})-52.092$

The square-wave behaviour is similar to that observed in differential pulse voltammetry (DPV), the peak current increases linearly with pulse amplitude according to the equation: $\operatorname{ip}(\mu \mathrm{A})=0.0619 \Delta \mathrm{E}(\mathrm{mV})-0.0272$ with a frequency of $80 \mathrm{~Hz}$ and a step of $4 \mathrm{mV}$, which promotes an effective scan rate of $50 \mathrm{mV} / \mathrm{s}$.

In the square wave voltammetry, it is presented in the same situation of commitment, which in differential pulse voltammetry, then with increasing pulse amplitude increases the width of half-peak therefore be chosen as optimal value $50 \mathrm{mV}$ pulse amplitude.

The variation of peak potential follows the equation: $\mathrm{Ep}(\mathrm{mV})=-0.7642 \Delta \mathrm{E}(\mathrm{mV})+59,289$

4) Influence of scan rate

As in previous studies have remained constant conditions of $\mathrm{pH}$, ionic strength and analyte concentration (10 $\left.\mu \mathrm{g} \cdot \mathrm{mL}^{-1}\right)$.

When scan rate is modified by cyclic voltammetry, the voltammograms (Figure 3) obtained clearly demonstrate the quasi-reversibility of the process the matter contribution is adsorptive.

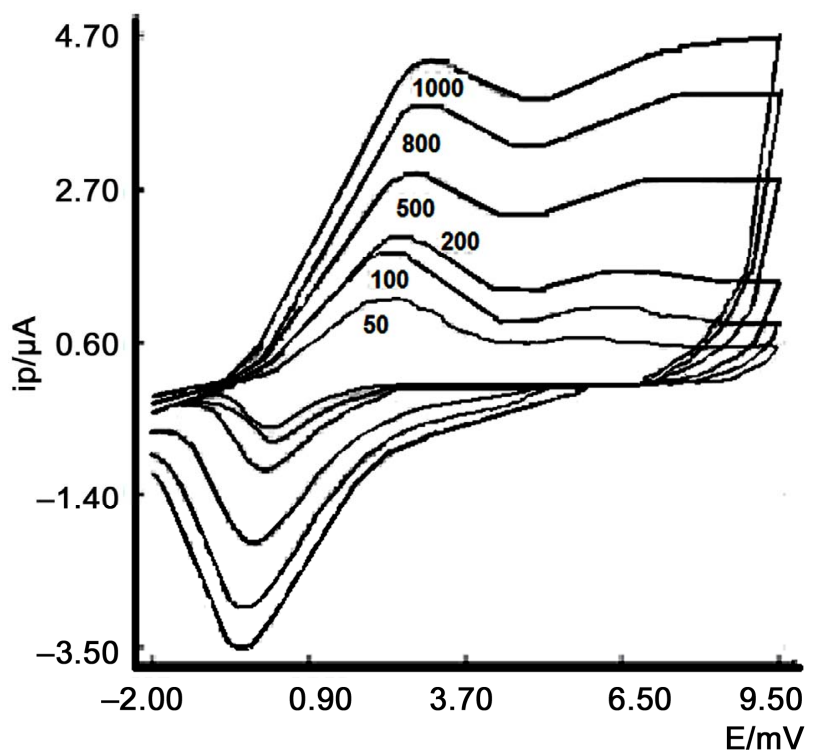

The determination of the number of electrons exchanged was carried out through a columbimetric process being, therefore, the reduction process is:

$$
P t(I I)-2 e^{-} \rightleftharpoons \operatorname{Pt}(I V)
$$

This confirms the reversibility of the process controlled by diffusion.

This fact can be corroborated by comparing the oxidation and reduction waves, as reflected in Figure 3.

\subsubsection{Calibration Curve and Limit of Detection}

After choosing the most appropriate measurement conditions for determining the compound under study, it was conducted to study the influence of analyte concentration using the following conditions (Table 1):

The analytical performance of the differential pulse voltammetry (DPV) method developed for trans- $\left[\mathrm{PtCl}_{2}\right.$ (dimethylamine)(isopropylamine)] determination was evaluated. From the voltammograms recorded for increasing amounts of trans-[ $\mathrm{PtCl}_{2}$ (dimethylamine)(isopropylamine)] using the optimized parameters described above, it is observed that the peak current increases with the analyte concentration in a large range $\left(0.05 \mu \mathrm{g} \cdot \mathrm{mL}^{-1}\right.$ to 10 $\left.\mu \mathrm{g} \cdot \mathrm{mL}^{-1}\right)$ with a good linearity according to $\operatorname{ip}(\mu \mathrm{A})=$ $0.62 \mathrm{C}\left(\mu \mathrm{g} \cdot \mathrm{mL}^{-1}\right)+6.63 ; \mathrm{r}=0.988$ with an $\operatorname{Er}(\%)=0.88$ and R.S.D of $1,69 \%\left(\mathrm{n}=10\right.$ at $10 \mu \mathrm{g} \cdot \mathrm{mL}^{-1}$ level). The minimum detectable amount was $102 \mu \mathrm{g} \cdot \mathrm{mL}^{-1}$ while a concentration of $340 \mu \mathrm{g} \cdot \mathrm{mL}^{-1}$ was calculated as determination limit.

It was proceeded in the same way when square wave voltammetry method was carried out. So, square-wave voltammograms were recorded for increasing amounts of trans-[ $\mathrm{PtCl}_{2}$ (dimethylamine) (isopropylamine)] in the optimal conditions founds for its determination. The linear response was found in the $0.05 \mu \mathrm{g} \cdot \mathrm{mL}^{-1}$ to $10 \mu \mathrm{g} \cdot \mathrm{mL}^{-1}$ range according to $\mathrm{I}=1.059 \mathrm{C}\left(\mu \mathrm{g} \cdot \mathrm{mL}^{-1}\right)+12.166 ; \mathrm{r}=$ 0.9902 . The sensitivity of the method was inferred from the LOD $(3 \sigma)\left(9 \quad 1 \mathrm{ng} \cdot \mathrm{mL}^{-1}\right)$ and LOQ $(10 \sigma)(303$ $\left.\mu \mathrm{g} \cdot \mathrm{mL}^{-1}\right)$ values. On the other hand, the R.S.D and $\mathrm{Er}$ values of $1.10 \%$ and $0.72 \%$ respectively $(\mathrm{n}=10$ at 18 $\mu \mathrm{g} \cdot \mathrm{mL}^{-1}$ level) indicated the accuracy and reproducibility of the proposed method.

Table 1. Condition for calibration curve.

\begin{tabular}{lcccc}
\hline & $\mathrm{pH}$ & $\begin{array}{c}\Delta \mathrm{E} \\
(\mathrm{mV})\end{array}$ & $\begin{array}{c}\mathrm{V} \\
(\mathrm{mV} / \mathrm{s})\end{array}$ & $\begin{array}{c}\text { Ionic } \\
\text { strength } \\
(\mathrm{M})\end{array}$ \\
\hline $\begin{array}{c}\text { Differential pulse } \\
\text { polarography }\end{array}$ & 8 & 50 & 25 & 0.5 \\
$\begin{array}{c}\text { Square wave } \\
\text { polarography }\end{array}$ & 8 & 50 & $\begin{array}{c}160 \\
(\text { Frequency }=50 \mathrm{~Hz}, \\
\text { Scan increment }=2 \mathrm{mV})\end{array}$ & 0.5 \\
\hline
\end{tabular}


In light of the results, the electrochemical technique that we are going to be used in future studies will be square wave voltammetry.

\subsection{Studies with Cucurbit [6] Uril}

Once the previous electrochemical studies were performed, it was proceeded to add cucurbit [6] uril in a 1:1 ratio with respect to the complex of platinum (II) that it is studied in this paper. The obtained results are summarized below.

\subsection{1. pH Influence}

It was proceeded in the same way when $\mathrm{pH}$ studywith CB [6] was carried out as when not using CB [6].

In this case, the optimal $\mathrm{pH}$ value was $\mathrm{pH} 3$ (Figure 4). By representing the variation of peak potential with respect to $\mathrm{pH}$ (Figure 4(b)) there are two straight sections with a clear variation of the slope, indicating that the compound under study has one dissociation constant, which correspond to the values of $\mathrm{K}=10^{-3.0}$.

Figure 5 shows the corresponding cyclic voltammetry voltammograms when the bare electrode is used and when the work electrode is modified with CB [6].

When we compare the voltamograms obtained by cyclic voltammetry at $\mathrm{pH} 3$ (Figure 5) with and without CB [6] observed that the wave oxidation and reduction are defined and increases the reversibility of the electrochemical oxidation.

\subsubsection{Determination of the Stoichiometry of the Complex}

The continuous variation method was employed in order to study the stoichiometry of the inclusion complex between trans- $\left[\mathrm{PtCl}_{2}\right.$ (dimethylamine)(isopropylamine)] and cucurbit [6] uril. With this objective, a series of solutions with equal total concentration of $2.5 \times 10^{-5} \mathrm{M}$, in which



Figure 4. Influence of pH.

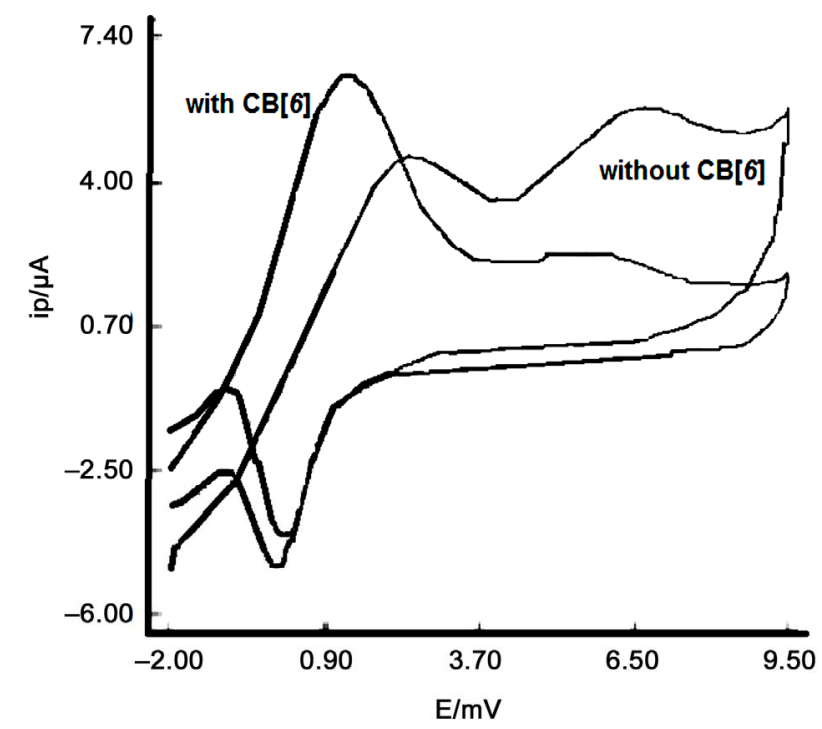

Figure 5. Comparison of voltamograms obtained by cyclic voltammetry at pH 3.

the mole ratio of the platinum complex ranged from 0 to 1 , were prepared in $0.5 \mathrm{M}$ phosphate buffer $\mathrm{pH}=3.0$ and the corresponding square wave voltammograms were recorded under the optimized conditions described above. From the plot $\left(\mathrm{Ip}_{\mathrm{I}} \mathrm{I} \mathrm{p}_{\mathrm{o}}\right)$ (where $\mathrm{Ip}_{\mathrm{o}}$ and Ip are the transPt(II)-CB [6] complex oxidation current in absence and in presence of $\mathrm{CB}[6]$ respectively) vs. the mole fraction of trans $-\mathrm{Pt}(\mathrm{II})\left(\mathrm{X}_{\text {trans }-\mathrm{P}(\mathrm{t}(\mathrm{II})}\right)$, a maximum at $\mathrm{X}_{\text {trans }-\mathrm{Pt}(\mathrm{II})}=0.5$ indicates that the stoichiometry of the trans-Pt(II)-CB [6] complex is $1: 1$.

Instrumental variables used in the electrochemical study of complex trans-Pt (II) with CB [6] agreed with those obtained in the previous study, that is without cucurbit [6] uril.

\subsection{Analytical Application}

Prior to the use of the method for determining the complex trans-[PtCl2(dimethylamine)(isopropylamine)] in urine, it is conducting a study of the inorganic salts present in a synthetic urine doped $10 \mu \mathrm{g} \mathrm{ml}-1$ and prepared in the laboratory with the composition that is contained in Table 2 [17].

To perform this experiment it was used the standard addition method, obtaining the equation ip $(\mathrm{uA})=$ $0.0664 \mathrm{C}\left(\mathrm{mg} \cdot \mathrm{mL}^{-1}\right)+0.484$, with a correlation coefficient of $\mathrm{R}=0.993$, when there is no $\mathrm{CB}[6]$ in the solution, and ip $(\mathrm{uA})=0.0232 \mathrm{C}\left(\mathrm{mg} \cdot \mathrm{mL}^{-1}\right)+0,108, \mathrm{R}=0.997$, when $\mathrm{CB}[6]$ is added.

When the current data obtained are extrapolated into the equations of the calibration curve, the concentration of trans-[PtCl2(dimethylamine)(isopropylamine)] complex obtained is $9.70 \mu \mathrm{g} \cdot \mathrm{mL}^{-1}$ (without $\mathrm{CB}$ [6]) and 9.64 $\mu \mathrm{g} \cdot \mathrm{mL}^{-1}$ (with CB [6]). 
Table 2. Synthetic urine composition.

\begin{tabular}{cccccc}
\hline $\mathrm{NaCl}$ & $\mathrm{KCl}$ & $\mathrm{CaCO}_{3}$ & $\mathrm{MgCl}_{2} \cdot 6 \mathrm{H}_{2} \mathrm{O}$ & $\mathrm{H}_{2} \mathrm{SO}_{4}(98 \%)$ & $\mathrm{NH}_{4} \mathrm{H}_{2} \mathrm{PO}_{4}$ \\
\hline$[\mathrm{C}]$ & $5.08 \mathrm{~g} \cdot \mathrm{L}^{-1}$ & $2.86 \mathrm{~g} \cdot \mathrm{L}^{-1}$ & $0.31 \mathrm{~g} \cdot \mathrm{L}^{-1}$ & $0.42 \mathrm{~g} \cdot \mathrm{L}^{-1}$ & $0.67 \mathrm{~mL} \cdot \mathrm{L}^{-1}$ \\
\hline
\end{tabular}

Given the suitability of the results, it was proceeded to determine the complex trans-[PtCl2(dimethylamine)(isopropylamine)] in human urine samples, the following procedure was used in the pretreatment of the sample and the subsequent action by square wave voltammetry (SWV).

The sample is doped with an aliquot of $10 \mu \mathrm{g} \cdot \mathrm{mL}^{-1}$ trans-[ $\left.\mathrm{PtCl}_{2}(\mathrm{dma})(\mathrm{ipa})\right]$ complex, then it is made the precipitation of proteins with $\mathrm{HClO}_{4} 1 \mathrm{M}$. The precipitate is digested for 48 hours, filtered and the filtrate was then brought to $\mathrm{pH}=3$ buffer solution with $0.5 \mathrm{M}$ and is performed by adding standard measurement by SWV. The plot of Ip versus $\left[\right.$ trans-[ $\left.\mathrm{PtCl}_{2}(\mathrm{dma})(\mathrm{ipa})\right]$, shows the excellent fit of the experimental data to the equations $\operatorname{ip}(\mu \mathrm{A})$ $=0.0619 \mathrm{C}\left(\mu \mathrm{g} \cdot \mathrm{mL}^{-1}\right)+0.647$, with a correlation coefficient of $\mathrm{R}=0.993$, when there is no $\mathrm{CB}$ [6] in the solution. And $\operatorname{ip}(\mu \mathrm{A})=0.0207 \mathrm{C}\left(\mu \mathrm{g} \cdot \mathrm{mL}^{-1}\right)+1.413, \mathrm{R}=$ 0.997 , when cucurbit [6] uril was added.

The procedure followed in the electrochemical study of human urine sample was the same as in the case of synthetic urine. By extrapolating the obtained data, the concentration of

trans- $\left[\mathrm{PtCl}_{2}\right.$ (dimethylamine)(isopropylamine)] complex was $9.97 \mu \mathrm{g} \cdot \mathrm{mL}^{-1}$ (without $\mathrm{CB}[6]$ ) and $9.81 \mu \mathrm{g} \cdot \mathrm{mL}^{-1}$ (with CB [6]).

The difference between the obtained data for human urine and synthetic urine can be caused because the matrix of human urine sample is much more complex than the synthetic urine matrix.

\section{Conclusion}

A sensitive square wave voltammetry (SWV) method to analyze trans-[ $\mathrm{PtCl}_{2}$ (dimethylamine)(isopropylamine)] complex has been developed and the mechanisms governing the electrochemical response have been elucidated. The proposed method can be applied to the determination of the studied Pt(II)-complex in biological fluids, with the inherent advantages of the electrochemical techniques, i.e., more economical and easy instrumentation with high accuracy and reproducibility as shown from the obtained results.

\section{Acknowledgements}

The authors thank to $\mathrm{Ph}$. Carmen Navarro for providing the platinum complex and to MICINN the economic support.

\section{REFERENCES}

[1] B. Lippert, "Cisplatin: Chemistry and Biochemistry of Leading Anticancer Drug," Wiley-VCH, Weinheim, 1999. doi:10.1002/9783906390420

[2] E. Wong and C. M. Giandomenico, "Current Status of Platinum-Based Antitumor Drugs," Chemical Reviews, Vol. 99, No. 9, 1999, pp. 2451-2466. doi:10.1021/cr980420v

[3] L. Kelland, "The Resurgence of Platinum-Based Cancer Chemotherapy," Natural Reviews on Cancer, Vol. 7, 2007, pp. 573-584. doi:10.1038/nrc2167

[4] N. J. Wheate and J. G. Collins, "Multi-Nuclear Platinum Complexes as Anti-Cancer Drugs," Coordination Chemistry Reviews, Vol. 241, No. 1-2, 2003, pp. 133-145. doi:10.1016/S0010-8545(03)00050-X

[5] N. J. Wheate and J. G. Collins, "Multi-Nuclear Platinum Drugs: A New Paradigm in Chemotherapy," Current Medicinal Chemistry-Anti-Cancer Agents, Vol. 5, No. 3, 2005, pp. 267-279. doi:10.2174/1568011053765994

[6] T. Dragovich, D. Mendelson, S. Kurtin, K. Richardson, D. Von Hoff and A. Hoos, "A Phase 2 Trial of the Liposomal DACH Platinum L-NDDP in Patients with TherapyRefractory Advanced Colorectal Cancer," Cancer Chemotherapy and Pharmacology, Vol. 58, No. 6, 2006, pp. 759-764. doi:10.1007/s00280-006-0235-4

[7] C. Lu, R. Pérez-Soler, B. Piperdi, G. L. Walsh, S. G. Swisher, W. R. Smythe, H. J. Shin, J. Y. Ro, L. Feng, M. Truong, A. Yalamanchili, G. Lópes-Berestein, W. K. Hong, A. R. Khokhar and D. M. Shin, Journal of Clinical Oncology, Vol. 23, No. 15, 2005, pp. 3495-3501. doi:10.1200/JCO.2005.00.802

[8] J. R. Rice, J. L. Gerberich, D. P. Nowotnik and S. B. Howell, "Preclinical Efficacy and Pharmacokinetics of AP5346, A Novel Diaminocyclohexane-Platinum TumorTargeting Drug Delivery System," Clinical Cancer Research, Vol. 12, 2006, pp. 2248-2254. doi:10.1158/1078-0432.CCR-05-2169

[9] M. Campone, J. M. Rademaker-Lakhai, J. Bennouna, S. B. Howell, D. P. Nowotnik, J. H. Beijnen and J. H. M. Schellens, "Phase I and Pharmacokinetic Trial of AP5346, a DACH-Platinum-Polymer Conjugate, Administered Weekly for Three out of Every 4 Weeks to Advanced Solid Tumor Patients," Cancer Chemotherapy and Pharmacology, Vol. 60, No. 4, 2007, pp. 523-533. doi:10.1007/s00280-006-0397-0

[10] Y. J. Jun, J. I. Kim, M. J. Jun and Y. S. Sohn, "Selective Tumor Targeting by Enhanced Permeability and Retention Effect. Synthesis and Antitumor Activity of Polyphosphazene-Platinum (II) Conjugates," Journal of Inorganic Biochemistry, Vol. 99, No. 8, 2005, pp. 1593-1601. doi:10.1016/j.jinorgbio.2005.04.019 
[11] P. Sood, K. B. Thurmond, J. E. Jacob, L. K. Waller, G. O. Silva, D. R. Stewart and D. P. Nowotnik, "Synthesis and Characterization of AP5346, a Novel Polymer-Linked Diaminocyclohexyl Platinum Chemotherapeutic Agent," Bioconjuate Chemistry, Vol. 17, No. 5, 2006, pp. 12701279. doi: $10.1021 / \mathrm{bc} 0600517$

[12] F. Kratz, I. A. Müller, C. Ryppa and A. Warnecke, "Prodrug Strategies in Anticancer Chemotherapy," ChemMedChem, Vol. 3, No. 1, 2008, pp. 20-53. doi:10.1002/cmdc.200700159

[13] K. Uekama, F. Hirayama, H. Arima and J. Incl, "Recent Aspect of Cyclodextrin-Based Drug Delivery System," Journal of Inclusion Phenomena and Macrocyclic Chemistry, Vol. 56, No. 1-2, 2006, pp. 3-8. doi:10.1007/s10847-006-9052-y

[14] R. Behrend, E. Meyer and F. Rusche, "I. Ueber Condensationsproducte aus Glycoluril und Formaldehyd," Justus Liebigs Annalen der Chemie, Vol. 339, No. 1, 1905, pp. 1-37. doi:10.1002/jlac.19053390102

[15] W. A. Freeman, W. L. Mock and N.-Y. Shih, "Cucurbituril," Journal of the American Chemical Society, Vol. 103, No. 24, 1981, pp. 7367-7368. doi:10.1021/ja00414a070

[16] J. Kim, I. S. Jung, S. Y. Kim, E. Lee, J. K. Kang, S. Sakamoto, K. Yamaguchi and K. Kim, "New Cucurbituril Homologues: Syntheses, Isolation, Characterization, and X-Ray Crystal Structures of Cucurbit[n]uril (n = 5, 7, and 8)," Journal of the American Chemical Society, Vol. 122, No. 3, 2000, pp. 540-541. doi:10.1021/ja993376p

[17] S. Liu, P. Y. Zavalij and L. Isaacs, "Cucurbit[10]uril," Journal of the American Chemical Society, Vol. 127, No. 48, 2005, pp. 16798-16799. doi:10.1021/ja056287n

[18] N. J. Wheate, "Cucurbit[n]uril: A New Molecule in HostGuest Chemistry," Australian Journal of Chemistry, Vol. 59, No. 5, 2006, p. 354. doi:10.1071/CH06066

[19] J. Lagona, P. Mukhopadhyay, S. Chakrabarti and L. Isaacs, "The Cucurbit[n]uril Family," Angewandte Chemie International Edition, Vol. 44, No. 31, 2005, pp. 4844-4870. doi:10.1002/anie.200460675

[20] K. Kim, N. Selvapalam, Y. H. Ko, K. M. Park and D. Kim, "Functionalized Cucurbiturils and Their Applications," Chemical Society Reviews, Vol. 36, No. 2, 2007, pp. 267-279. doi:10.1039/b603088m

[21] A. P. Day, R. J. Arnold, B. Blanch and J. Snushall, "Controlling Factors in the Synthesis of Cucurbituril and Its Homologues," The Journal of Organic Chemistry, Vol. 66, No. 24, 2001, pp. 8094-8100. doi:10.1021/jo015897c

[22] D. Whang, J. Heo, J. H. Park and K. Kim, "A Molecular Bowl with Metal Ion as Bottom: Reversible Inclusion of Organic Molecules in Cesium Ion Complexed Cucurbituril," Angewandte Chemie International Edition, Vol. 37, No. 1-2, 1998, pp. 78-80. doi:10.1002/(SICI)1521-3773(19980202)37:1/2<78::AID -ANIE78>3.0.CO;2-9

[23] H.-J. Buschmann, E. Cleve, E. Schollemeyer, "Cucurbituril as a Ligand for the Complexation of Cations in Aqueous Solutions," Inorganica Chimica Acta, Vol. 193, No. 1, 1992, pp. 93-97. doi:10.1016/S0020-1693(00)83800-1
[24] Y. M. Jeon, H. Kim, D. Whang and K. Kim, Journal of Physical Chemistry Society, Vol. 118, No. 40, 1996, pp. 9790-9791.

[25] N. J. Wheate, P. G. A. Kumar, A. M. Torres, J. R. Aldrich-Wringht and W. S. Price, "Examination of Cucurbit [7] uril and Its Host-Guest Complexes by Diffusion Nuclear Magnetic Resonance," Journal of Physical Chemistry B, Vol. 112, No. 8, 2008, pp. 2311-2314. doi:10.1021/jp709847p

[26] K. B. Tarmyshov and F. Muller-Plathe, "Ion Binding to Cucurbit[6]uril: Structure and Dynamics," Journal of Physical Chemistry B, Vol. 110, No. 29, 2006, pp. 1446314468. doi:10.1021/jp0622637

[27] Osaka, M. Kondou, N. Selvaplan, S. Samal, K. Kim, M. V. Rekharsky, Y. Inoue and R. Arakawa, "Characterization of Host-Guest Complexes of Cucurbit[n]uril $(n=6,7)$ by Electrospray Ionization Mass Spectrometry," Journal of Mass Spectrometry, Vol. 41, No. 2, 2006, pp. 202-207. doi: $10.1002 / \mathrm{jms} .978$

[28] W.-H. huang, P. Y. Zavalij and L. Isaacs, "Chiral Recognition inside a Chiral Cucurbituril ${ }^{\dagger}, "$ Angewandte Chemie International Edition, Vol. 46, No. 39, 2007, pp. 74257427. doi:10.1002/anie.200702189

[29] Q. An, G. Li, C. Tao, Y. Li, Y. Wu and W. Zang, "A General and Efficient Method to Form Self-Assembled Cucurbit[N]Uril Monolayers on Gold Surfaces," Chemical Communications, No. 17, 2008, pp. 1989-1991. doi:10.1039/b719927a

[30] N. J. Wheate, D. P. Buck, A. I. Day and J. G. Collins, “Cucurbit[n]uril Binding of Platinum Anticancer Complexes," Dalton Transactions, Vol. 17, No. 3, 2006, pp. 451458. doi:10.1039/b513197a

[31] S. Kemp, N. J. Wheate, S. Wang, J. G. Collins, S. F. Ralph, A. I. Day, V. J. Higgings and J. R. Aldrich-Wright, "Encapsulation of Platinum(II)-Based DNA Intercalators within Cucurbit[6,7,8]urils," Journal of Biological Inorganic Chemistry, Vol. 12, No. 7, 2007, pp. 969-979. doi:10.1007/s00775-007-0269-z

[32] N. J. Wheate, R. I. Taleb, A. M. Krause-Heuer, R. L. Cook, S. Wang, V. J. Higgings and J. R. Aldrich-Wright, Dalton Transactions, 2007, pp. 505-5064.

[33] J. M. Perez, L. R. Kelland, E. I. Montero, F. E. Boxal, M. Fuertes, C. Alonso and C. Navarro-Ranninger, "Antitumor and Cellular Pharmacological Properties of a Novel Platinum (IV) Complex: Trans-[ $\mathrm{PtCl}_{2}(\mathrm{OH})_{2}$ (Dimethylamine)(Isopropylamine)]," Molecular Pharmacology, Vol. 63, No. 4, 2003, pp. 903-944. doi:10.1124/mol.63.4.933

[34] J. M. Perez, E. I. Montero, A. G. Quiroga, M. A. Fuertes, C. Alonso and C. Navarro-Ranninger, "Cellular Uptake, DNA Binding and Apoptosis Induction of Citotoxic Trans$\left[\mathrm{PtCl}_{2}(\mathrm{~N}, \mathrm{~N}-\mathrm{Dimethylamine})(\right.$ Isopropylamine) $]$ in A2780cisR Ovarian Tumor Cells," Metal Based Drugs, Vol. 8, No. 1, 2001, pp. 29-37. doi:10.1155/MBD.2001.29

[35] J. M. Perez, E. I. Montero, A. M. González, A. AlvarezValdés, C. Alonso and C. Navarro-Ranninger, "Apoptosis Induction and Inhibition of $\mathrm{H}$-Ras Overexpresion by Novel Trans-[ $\left.\mathrm{PtCl}_{2}\right)$ (Isopropylamine)(amine')] Complexes," Journal of Inorganic Biochemistry, Vol. 77, No. 1, 1999, pp. 37-42. 
[36] E. I. Montero, J. M. Perez, A. Schwartz, M. A. Fuertes, J. M. Maligne, C. Alonso, M. Leng and C. Navarro-Ranninger, "Apoptosis Induction and DNA Interstrand CrossLink Formation by Citotoxic Trans-

$\left[\mathrm{PtCl}_{2}\left(\mathrm{NH}\left(\mathrm{CH}_{3}\right)_{2}\left(\mathrm{NH}_{2}\left(\mathrm{CH}\left(\mathrm{CH}_{3}\right)_{2}\right]\right.\right.\right.$ : Cross-Linking between $\mathrm{d}(\mathrm{G})$ and Complementary $\mathrm{d}(\mathrm{G})$ within Oligonucleotide Duplexes," Biochemistry (Chemical Biology), Vol. 3, No. 1, 2002, pp. 101-107.
doi:10.1002/1439-7633(20020104)3:1<61::AID-CBIC61 $>3.0 . \mathrm{CO} ; 2-\mathrm{I}$

[37] B. J. Stevens, "Clinical Analysis by Atomic Absorption," Department of Pathology. The Royal Children's Hospital, Melbourne, 1970.

\section{Abbreviations}

Trans-Pt(II), trans- $\mathrm{Pt}\left[\mathrm{Cl}_{2}(\mathrm{dma})(\mathrm{ipa})\right]$ (trans $-\mathrm{Pt}\left[\mathrm{Cl}_{2}\right.$ (Dimethylamine)(isopropylamine)]);

DP (differential pulse voltammetry);

$\mathrm{RT}$, room temperature

SWV (square wave voltammetry);

$\mathrm{CB}[n]$ (cucurbit $[n]$ urils);

cis-DDP (cis-diamminedichloroplatinum (II)) 